\title{
Menedžment v vzgoji in izobraževanju
}

\author{
Marija Velikonja
}

Deset let je minilo od prvih tridnevnih seminarjev za ravnatelje osnovnih in srednjih šol, ki so pomenili začetek usposabljanja vodstvenih delavcev v vzgoji in izobraževanju iz menedžmenta. Malo pred to pomembno obletnico, jeseni 1995, je založba Zavoda RS za šolstvo izdala knjigo Menedžment v vzgoji ni izobraževanju, zbornik gradiv in hkrati priročnik za ravnateljice in ravnatelje vrtcev, osnovnih in srednjih šol ter domov. Knjigo je uredila Marija Velikonja.

Knjigo so oblikovali predavatelji v »šoli za ravnatelje«, to je 200-urnem programu usposabljanja ravnateljev, po triletnih izkušnjah, ko je program usposabljanja končalo 305 ravnateljic in ravnateljev vzgojno-izobraževalnih zavodov. $\mathrm{K}$ oblikovanju zbornika so bili povabljeni predavatelji, ki so pogosteje in uspešno predavali ravnateljem in jih usposabljali za različna področja vodenja. Tako je nastalo trinajst besedil, ki jih je pripravilo štirinajst avtorjev. V uvodu lahko preberemo, da ne gre za »učbenik iz menedžmenta, saj ne govori o vseh področjih vodenja, lahko pa je priročnik za vodenje vzgojno-izobraževalnega zavoda, ki bo ravnatelju marsikdaj pomagal, da bo v njem našel odgovore na številna vprašanja«. Večji del prispevkov govori o vodenju ljudi in pedagoškem vodenju, nekaj besedil pa tudi o načrtovanju, organiziranju in vrednotenju, to je drugih sestavinah menedžmenta.

Zbornik začenja tema o skupinsko-dinamičnih zakonitostih vodenja (dr. J. Bečaj). Avtor piše o človekovih socialnih potrebah in socialni motivaciji, pojasnjuje pojem skupine, razčlenjuje bistvene značilnosti skupin, temeljne naloge vodenja, nasprotja $\mathrm{v}$ skupinski dinamiki in vodenju itn. Poudarja, da mora biti organizacija skladna $\mathrm{z}$ lastnostmi ljudi, ki jo sestavljajo (kultura), in z njihovimi individualnimi potrebami in cilji. Prilagajati se mora svojim članom in ne nasprotno. Avtor pa ne ostaja le pri opisovanju splošnih teoretičnih pojavov, pač pa za ponazoritev dodaja mnoge primere iz šolske prakse.

Na skupinsko vodenje in upravljanje v zavodih opozarja dr. J. Mayer, saj, tako piše, prevladuje pri vodenju na Slovenskem tip »sam svoj mojster«. Vodenje menedžerske skupine zahteva človeka s prožno osebnostno strukturo, pomembna je sposobnost njegovega prilagajanja vsakokratnim okoliščinam in interakcijam v medosebni dinamiki.

Za slovenski šolski menedžment je posebej zanimiv prispevek o ravnateljevem ravnanju (dr. B. Lipičnik). Avtor je s posebno raziskavo skušal ugotoviti najpogostejši način ravnanja slovenskih ravnateljev, preskusiti sestavljanje »dobrih« in »slabih« skupin in določiti podmene, na podlagi katerih bi lahko ugotavljali učinke izobraževanja ravnateljev. S posebnim vprašalnikom je ugotovil, da je »povprečen« slovenski ravnatelj pri svojem ravnanju predvsem usmerjen v ljudi, kot »orodje dela« pa uporablja predvsem ustvarjalnost, manj ga pri tem zanimajo dosežki in sam sistem dela. V drugem delu raziskave pa je ugotovil, da je na osnovi ideje o komplementarni skupini mogoče skupino sestaviti in $\mathrm{z}$ veliko verjetnostjo napovedati njeno uspešnost, kar daje ideji veliko praktično uporabnost.

Med pomembnejšimi besedili je tudi prispevek o stilih razmiš- ljanja ravnateljev avtorice dr. L. Magajna. Raziskava, ki jo je avtorica opravila med ravnatelji, je pokazala, da slovenski ravnatelji rešujejo probleme največkrat analitično (40\%), med posameznimi skupinami pa so pomembne razlike. Spoznanja o prednostih in pomanjkljivostih lastnih načinov miselnega odzivanja lahko veliko pomagajo pri izbiri sodelavcev in pri nadaljnjem usposabljanju.

Ravnatelj mora dobro obvladovati tudi medosebne odnose in učinkovito reševati konflikte (dr. S. Možina: Vodenje in vedenje $\mathrm{v}$ organizaciji). Njegovo delo temelji na dolgoročnih ciljih in strateškem načrtovanju (dr. M. Tavčar: Strateško načrtovanje). Skrbno sodeluje tudi pri načrtovanju in pripravi izobraževalnovzgojnega procesa (dr. M. Kramar).

Skoraj tretjina knjige je namenjena pedagoškemu vodenju (dr. A. Tomić). Avtorica seznanja bralca z osnovnimi pojmi o vodenju (piše o slovenskih izkušnjah o tem, kako vidijo učitelji slog ravnateljevega vodenja), piše o komunikaciji in o ravnatelju kot o osrednjem komunikatorju, razčlenjuje ravnateljevo vlogo pri načrtovanju dela, pri spremljanju pedagoškega procesa ( $v$ tem delu največ piše o opazovanju pedagoškega procesa) ter opozarja na pravila dobre pedagoške konference. Med besedila, ki jih dopolnjuje s svojimi bogatimi izkušnjami, pridobljenimi v šolski praksi ali kot predavateljica na seminarjih za učitelje in vodstvene delavce, včlenjuje številne vprašalnike, primere in dodaja praktična navodila.

Ravnateljeva vloga je tudi razvijati in spodbujati razvoj posameznih delavcev vzgojno-izobraževalnega zavoda. O tem govori sestavek Ravnatelj - spodbujevalec izpopolnjevanja in akcijskega raziskovanja učiteljev avtorice dr. Barice Marentič Požarnik. Le-ta predstavlja ravnateljevo vlogo pri strokovnem izpopolnjevanju učiteljev na šoli, pri akcijskem raziskovanju na šoli ter pri učiteljevi strokovni rasti.

Ravnateljeva vloga v vrednotenju vzgojno-izobraževalnega dela (dr. V. Mužić) je eno redkih besedil na to temo in eno prvih, ki poglobljeno razčlenjuje, kako ravnatelj načrtuje in izpelje postopke vrednotenja. Opozarja tudi, kako pomembna je ravnateljeva vloga pri tem. S svojim delovanjem ravnatelj lahko veliko pripomore $\mathrm{k}$ vrednotenju in odločanju o uresničevanju vzgojnoizobraževalnih nalog.

V zadnjem delu so predstavljeni še prispevki Izobraževalna tehnologija - ravnatelj - šola (T. Skulj), Trženje: nujna podpora za učinkovitejše upravljanje šol (dr. Miro Kline, J. Velikonja).

Recenzent knjige dr. Metod Resman je v strokovni oceni med drugim zapisal, da je publikacija dokument o nastanku prve šole za ravnatelje. $» \mathrm{~V}$ delu imajo posebno vrednost empirični podatki o stališčih in ravnanju udeležencev šole, ki so jih zbrali posamezni nosilci usposabljanja. Posebno vrednost pa ob tem zasluži tudi evalvacija dela šole za ravnatelje, v kateri se odražajo tudi značilnosti, posebnosti razmišljanj in dela naših ravnateljev. Pravzaprav so tovrstne evalvacije temelj za prihodnje načrtovanje dela šole in usposabljanje ravnateljev za vodenje šole. $V$ delu zbrana poglavja pa slej ko prej ostajajo aktualna tudi za usposabljanje ravnateljev v prihodnje.« 